\title{
HUMAN MILK BANK: THE BREASTFEEDING COUNSELING AND THE DURATION OF EXCLUSIVE BREASTFEEDING
}

\author{
Maria Claudia Diniz Figueiredo, Márcia Penna Bueno ${ }^{1}$, Camila Cury Ribeiro', \\ Patrícia Azevedo Lima², Ísis Tande Silva²
}

\begin{abstract}
Objective: To identify which sociodemographic factors are associated with early weaning and compare the duration of exclusive breast feeding between mothers which received counseling about maternal feeding and mothers which was not guided for these practices. Methods: A cross-sectional study with 25 mothers that received counseling about the benefits of maternal feeding in the human milk bank and 25 from a university hospital that were not counseled. Data were collected using a structured questionnaire addressing mother-related data, the infant and the breastfeeding in the first semester. Comparison and odds ratio were the statistical analyses adopted. Results: There was not a significant difference of the duration of exclusive breast-feeding between the two groups $(p=0,524)$. Among mothers in the human milk bank group that discontinued early exclusive breast-feeding, fewer children $(p=0,034)$ and a higher frequency of maternal work $(p=0,022)$ were observed. Wile, in the university hospital group low education $(p<0.001)$ and lower income $(p=0.009)$ were prevalent. In the totality of the sample, the interruption of exclusive breast-feeding was associated with $<1$ children $(O R=0.21, p=0.030)$, the presence of a partner $(O R=0.046, p=0.001)$ and the use of bottles or pacifiers $(O R=87.5, p<0.001)$. In both groups, the most cited motivation for exclusive breast-feeding discontinuation was the medical assistance. It was observed the absence of a specific standard guideline provided in the Human Milk Bank, and less than the recommended number of consultations in the literature. Conclusions: Socioeconomic factors and inadequate incentives negatively influence the duration of exclusive breast feeding. It was verified the need to provide standardized and more frequent counseling for effective reduction of early weaning.
\end{abstract}

Key words: breast-feeding, early weaning, milk banks, milk human.

\section{INTRODUCTION}

Exclusive breastfeeding (EBF) until the sixth month of life has been the subject of worldwide interest, and the benefits of this practice to mother and child are regularly noted. In addition to being an excellent source of nutrition for the growth and development of children, breast milk is associated with a reduction in various diseases ${ }^{1}$ such as anemia ${ }^{2,3}$ gastrointestinal infections, atopy and asthma4. It is now known that, due to the presence of numerous protective factors in its composition, the use of breast milk is the most impactful strategy in reducing mortality in children under five years $^{5}$. EBF is thus recommended until the sixth month of life and breast feeding with complementary food up to 2 years of age or older. ${ }^{5}$

For decades, breastfeeding was a second priority for the health of children, and the use of artificial feeding was increased, particularly through the support of health professionals. ${ }^{6}$ A discreet, but progressive reversal of this situation has now been observed through national studies ${ }^{7}$, however, the latest survey conducted in this area demonstrates that the breastfeeding practices in Brazil are still far from the ideal level. ${ }^{8}$

Faced with this finding, several initiatives have emerged with the aim of increasing breastfeeding rates. The Human Milk Bank (HMB) is one of these initiatives, and is defined as a specialised service for the promotion of breastfeeding, and its protection and support. Activities include the distribution of human milk for infants unable to receive it from their mothers, as well as lectures, demonstrations and trainings. ${ }^{9}$

The identification of guidelines has been shown to be a favourable factor for successful breastfeeding. Studies suggest that the promotion of guidance on the benefits and techniques of breastfeeding is related to EBF being used for longer periods ${ }^{10,11 .}$ The Ministry of Health provides some essential guidance for mothers after birth. This includes orientation on normal behaviour in babies, the number of feedings needed, the best duration of breastfeeding, the appearance of milk, the correct way to handle the breast when feeding and the position of both mother and infant ${ }^{5}$. Several external

\footnotetext{
1 Departamento de Enfermagem e Nutrição, Universidade de Taubaté (Unitau) - Taubaté (SP), Brasil .

2 Departamento de Nutrição, Faculdade de Saúde Pública (FSP), Universidade de São Paulo (USP) - São Paulo (SP), Brasil. Corresponding author: Maria Claudia Diniz Figueiredo. E-mail: claudia.nutri@outlook.com
}

Suggested citation: Figueiredo MCD, Bueno MP, Ribeiro CC, Lima PA, Silva IT. Human milk bank: the breastfeeding counseling and the duration of exclusive breastfeeding. Journal of Human Growth and Development. 25(2): 204-210. DOI: http://dx.doi.org/ $10.7322 /$ jhgd. 103016

Manuscript submitted: mar 14 2015. Accepted for publication: jul 102014. 
factors are related to this practice, however, including the number of children, age, education, income, and marital status, compared to the use of artificial bottle feeding ${ }^{8}$.

This study was conducted to identify sociodemographic factors associated with early weaning and to compare exclusive breastfeeding duration between mothers who have received human milk bank guidance on the practice and those who have not.

\section{METHODS}

A cross-sectional study was conducted with mothers of infants 7-12 months of age. During the months of June and July 2012 data was collected from 276 medical records, 85 mothers enrolled in the HMB and 191 mothers enrolled at the University Hospital (UH) in São Paulo, Brazil. Of these, 25 mothers from each institution met the requirements for participation in the study and also agreed to participate. Mothers who had their children between July and December 2011 at UH were included, as were mothers who attended the HMB between July and December 2011, the latter of whom received the latest guidance in the first month of breastfeeding. The exclusion criteria were mothers whom it was not possible to obtain contact, mothers whose interviews did not continue to the end of the period, and mothers whose infants were premature, or who had respiratory infections, severe diarrhoea, infectious diseases, an allergy to milk, problems with their metabolism, or required hospitalisation in the first six months of life. Mothers from the UH who had received guidance on breastfeeding were also excluded.

All participants were asked to participate in the study via telephone, on July 2012. After the recorded participation acceptance, a pre-prepared questionnaire, based on the model that was applied in the Second Breastfeeding Prevalence Study in the Brazilian Capital and Federal District ${ }^{8}$, and the model by Calegari ${ }^{12}$, which addresses socioeconomic data about the mother, infant, EBF time, reason for suspension of EBF, the use of artificial nipples, and breast problems during the breastfeeding period. The city HMB, where the survey was conducted, did not have a standard protocol by which guidelines were provided or about the number of consultations to be held. Guidelines were given at the time of consultation, when they were requested, or were directed to the specific complaints of mothers. To better understand the breadth of service, mothers using this institution were also asked about the orientation received and the number of queries.

Statistical analysis was performed using the Statistical Package for the Social Sciences $®$ (SPSS) version 16.0 (SPSS INCORPORATION, 2000). The significance level considered was $5 \%$. Among the analyses, compared (Test $-\mathrm{X}^{2}$ ) factors associated with breastfeeding among individuals of HMB and $\mathrm{UH}$ who performed EBF and between individuals of $\mathrm{HMB}$ and $\mathrm{UH}$ than held EBF. The odds ratio was applied to the total population of the study in order to identify the factors associated with increased risk of EBF interruption. The sample size was determined according to Hulley et al. ${ }^{13}$. The statistical power established in the calculation was $80 \%$ and the outcome variable was breastfeeding duration. To a standardised magnitude of effect of 0.8 (E/S) of 0.05 á and $B=0.20 \%$ a total of 21 individuals was required in each group, to verify an increase of at least one month in breastfeeding duration $(E=0.8$; $\mathrm{S}=0.8$ ). To minimise possible losses in the study $20 \%$ was added to the sample size, totalling $n=25$ per group.

This study was approved by the Research Ethics Committee of the University of Taubaté, Sao Paulo, Brazil (CEP/UNITAU No. 094/12).

\section{RESULTS}

The mean age of the respondents was $27.7 \pm 6.7$ years, and they had a median of 1 for the number of children. Most of the interviewees had completed high school or higher education $(60 \%)$ and had a monthly income $1-3$ times the minimum wage $(82 \%) .54 \%$ of mothers were married and $36 \%$ reported a stable union. During the first six months postpartum, $16 \%$ of mothers had paid work outside the home (Table 1 ). Reasons the 25 mothers from the HMB gave for seeking help were problems in the breasts such as fissures, engorgement or mastitis (32\%), breastfeeding difficulty due to incorrect handling, worries about not having enough milk (60\%) and recommendation by their own mother ( $8 \%)$.

Initially, it is important to note the details of the guidance provided to the HMB group, as this divides the mothers into subgroups according to the type of guidance received, which can be correlated with the use of EBF until the sixth month of their child's life. The guidelines described by the interviewees in the HMB group randomly included information such as "benefits of breast milk", "care of the breast" and "breastfeeding techniques." There was a higher percentage of guidance about the "benefits of breast milk" among mothers who used EBF until the sixth month (60\%). In addition to guidance on the benefits of EBF, the mothers who used EBF reported guidelines on breast care $(60 \%)$ and feeding techniques (60\%). Of the mothers who did not use EBF $25 \%$ reported having information about its benefits, $45 \%$ about breast care and $75 \%$ about techniques. Despite these results, there was no significant difference between EBF and nonexclusive breastfeeding groups (NEBF) in those who received guidelines $(p=0.286)$.

An average of $2.9 \pm 1.9$ visits to the institution was noted among those interviewed in HMB. Mothers belonging to the UH group stayed in the hospital only for delivery and subsequently attended only on routine paediatric visits.

The prevalence of EBF until the sixth month of life in the total sample was $22 \%$, with a median of 2.75 months. There was no significant difference when comparing the duration of exclusive breastfeeding between the HMB group and the UH group ( $p=0.524)$ (Table 2$)$. 
Table 1: Socio-demographic characterization of mothers, according to home institution, Taubaté, São Paulo, Brazil

\begin{tabular}{|c|c|c|c|}
\hline Variables & $\begin{array}{c}\text { Institution } \\
\text { HMB } \\
\text { m } \pm \mathbf{d p}\end{array}$ & $\begin{array}{c}\text { TUH } \\
m \pm d p\end{array}$ & $\begin{array}{c}\text { Total } \\
\mathbf{m} \pm \mathbf{d p}\end{array}$ \\
\hline Age (years) & $29.5 \pm 4.9$ & $26 \pm 7.9$ & $27.7 \pm 6.7$ \\
\hline Schooling & n (\%) & n (\%) & n (\%) \\
\hline $\begin{array}{l}\text { Illiterate } \\
\text { Incomplete Elementary School } \\
\text { Complete Elementary School } \\
\text { Incomplete High School } \\
\text { Complete High School } \\
\text { Incomplete University } \\
\text { Complete University }\end{array}$ & $\begin{array}{c}0(0) \\
0(0) \\
0(0) \\
2(8) \\
6(24) \\
12(48) \\
5(20)\end{array}$ & $\begin{array}{c}0(0) \\
10(40) \\
2(8) \\
6(24) \\
7(28) \\
0(0) \\
0(0)\end{array}$ & $\begin{array}{c}0(0) \\
10(20) \\
2(4) \\
8(16) \\
13(26) \\
12(24) \\
5(10)\end{array}$ \\
\hline $\begin{array}{l}\text { Income (minimum salary) } \\
1 \text { to } 3 \\
4 \text { to } 10 \\
\text { Above } 10\end{array}$ & $\begin{array}{c}16(64) \\
9(36) \\
0(0)\end{array}$ & $\begin{array}{c}25(100) \\
0(0) \\
0(0)\end{array}$ & $\begin{array}{l}41(82) \\
9(18) \\
0(0)\end{array}$ \\
\hline $\begin{array}{l}\text { Maternal work } \\
\text { Yes } \\
\text { No }\end{array}$ & $\begin{array}{c}7(28) \\
18(72)\end{array}$ & $\begin{array}{c}1(4) \\
24(96)\end{array}$ & $\begin{array}{c}8(16) \\
42(84)\end{array}$ \\
\hline $\begin{array}{l}\text { Marital status } \\
\text { Single } \\
\text { Married } \\
\text { Stable Union } \\
\text { Separated }\end{array}$ & $\begin{array}{c}2(8) \\
19(76) \\
4(16) \\
0(0)\end{array}$ & $\begin{array}{c}2(8) \\
8(32) \\
14(56) \\
1(4)\end{array}$ & $\begin{aligned} 4 & (8) \\
27 & (54) \\
18 & (36) \\
1 & (2)\end{aligned}$ \\
\hline
\end{tabular}

HMB: human milk bank; TUH: University Hospital of Taubaté, São Paulo, Brazil; $m$ = average; SD = standard deviation; $\mathrm{n}$ : number; \%: percentage.

Table 2: Median and prevalence of exclusive breastfeeding (EBF) until the sixth month of life between mothers, according to home institution, Taubaté, São Paulo, Brazil

\begin{tabular}{|c|c|c|c|c|}
\hline Variable & $\begin{array}{c}\text { Institution } \\
\text { HMB }\end{array}$ & UH & $\mathbf{p}$ & TOTAL \\
\hline EBF until the 6th month & n (\%) & n (\%) & 0.733 & n (\%) \\
\hline Yes & $5(20)$ & $6(24)$ & & $11(22)$ \\
\hline No & $20(80)$ & $19(76)$ & & $39(78)$ \\
\hline The median duration of AME (months) & $\begin{array}{c}\text { HMB } \\
3\end{array}$ & $\begin{array}{l}\text { UH } \\
2\end{array}$ & $\begin{array}{c}\mathbf{p} \\
0 . \stackrel{5}{5} 4\end{array}$ & $\begin{array}{c}\text { TOTAL } \\
2.75\end{array}$ \\
\hline
\end{tabular}

Analysis of the differences between the groups was performed by test $(\mathrm{c})^{2}$, with $\mathrm{p}<0.05$. HMB = human milk bank; $\mathrm{UH}=$ University Hospital; $\mathrm{EBF}=$ exclusive breastfeeding; $\mathrm{n}=$ number; $\%$ = percentage

In the comparative analysis of mothers using HMB and UH, separately for those breastfeeding exclusively up to six months and those who did not, there were fewer children $(p=0.034)$ and a higher maternal employment rate $(p=0.022)$ in the HMB group who discontinued EBF before the six months compared to the same UH group. Being less educated $(p<0.001)$ and having a lower income ( $p=0.009$ ) were variables that prevailed among the UH group who discontinued EBF before six months. Even the UH group that continued EBF for six months had a lower income than the HMB group (Table 3).

The main factors associated with EBF in the total study population can be seen in Table 4 .

EBF interruption before six months and having no other children were associated $(\mathrm{OR}=0.21$; CI $95 \%=0.05-0.92 ; p=0.030)$, living withtheir partner $(O R=0.046 ;$ CI $95 \%=0.004-0.48$; $\mathrm{p}=0.001)$ and the use of artificial nipples (OR $=$ 87.5, 95\% CI 95\% = 8.76 - 873.83, $\mathrm{P}<0.001)$. When the associations were tested separately for the HMB and UH groups (data not available in the table), there was only an association in the UH group with the use of nozzles and exclusive breastfeeding for 6 months (OR = 36.0, CI 95\% = 2.59 - 501.27, $\mathrm{p}=0.001)$.

There was no difference between the groups with respect to the reasons cited for EBF interruption. Among the reasons given for stopping, medical reasons were the most cited among both group of mothers HU (52.6\%) and HMB (75\%) mothers (Figure 1).

There was a low EBF uptake in the first six months of infant life, regardless of whether the participants had received guidelines about the practice. Caldeira et al. ${ }^{14}$ found a low percentage of EBF in the first half of the life of infants from 
Table 3: Comparison of demographic parameters according to the mother's type of breastfeeding and home institution, Taubaté, São Paulo, Brazil

\begin{tabular}{|c|c|c|c|c|c|c|c|}
\hline \multirow[b]{2}{*}{ Variables } & \multirow[b]{2}{*}{ Categories } & \multicolumn{2}{|c|}{ EBF } & \multirow[t]{2}{*}{$\mathbf{P}$} & \multicolumn{2}{|c|}{ NEBF } & \multirow[t]{2}{*}{$\mathbf{p}$} \\
\hline & & $\begin{array}{l}\text { HMB } \\
\text { n (\%) }\end{array}$ & $\begin{array}{c}\text { UH } \\
\text { n (\%) }\end{array}$ & & $\begin{array}{l}\text { HMB } \\
\text { n (\%) }\end{array}$ & $\begin{array}{c}\text { UH } \\
\text { n (\%) }\end{array}$ & \\
\hline Maternal Age & $\begin{array}{l}<30 \text { years } \\
\geq 30 \text { years }\end{array}$ & $\begin{array}{l}1(20) \\
4(80)\end{array}$ & $\begin{array}{l}4(67) \\
2(33)\end{array}$ & 0.122 & $\begin{array}{l}10(50) \\
10(50)\end{array}$ & $\begin{array}{l}13(68) \\
6(32)\end{array}$ & 0.242 \\
\hline $\begin{array}{l}\text { Number of } \\
\text { children }\end{array}$ & $\begin{array}{l}>1 \\
\leq 1\end{array}$ & $\begin{array}{l}3(60) \\
2(40)\end{array}$ & $\begin{array}{l}5(83) \\
1(17)\end{array}$ & 0.387 & $\begin{array}{c}4(20) \\
16(80)\end{array}$ & $\begin{array}{l}10(53) \\
9(47)\end{array}$ & $* 0.034$ \\
\hline Work & $\begin{array}{l}\text { Yes } \\
\text { No }\end{array}$ & $\begin{array}{c}0(0) \\
5(100)\end{array}$ & $\begin{array}{c}0(0) \\
6(100)\end{array}$ & - & $\begin{array}{c}7(35) \\
13(65)\end{array}$ & $\begin{array}{c}1(5) \\
18(95)\end{array}$ & $0.022 *$ \\
\hline Schooling & $\begin{array}{c}\text { Full ES } \\
\text { HS and/or higher }\end{array}$ & $\begin{array}{c}0(0) \\
5(100)\end{array}$ & $\begin{array}{l}3(50) \\
3(50)\end{array}$ & 0.067 & $\begin{array}{c}0(0) \\
20(100)\end{array}$ & $\begin{array}{c}9(47) \\
10(53)\end{array}$ & $<0.001 *$ \\
\hline Family income & $\begin{array}{c}1 \text { to } 3 \mathrm{MS} \\
4 \text { to } 10 \mathrm{MS}\end{array}$ & $\begin{array}{l}2(40) \\
3(60)\end{array}$ & $\begin{array}{c}6(100) \\
0(0)\end{array}$ & $0.026 *$ & $\begin{array}{l}14(70) \\
6(30)\end{array}$ & $\begin{array}{c}19(100) \\
0(0)\end{array}$ & $* 0.009$ \\
\hline $\begin{array}{l}\text { Marital status } \\
\text { (live with spouse) }\end{array}$ & $\begin{array}{l}\text { No } \\
\text { Yes }\end{array}$ & $\begin{array}{l}2(40) \\
3(60)\end{array}$ & $\begin{array}{l}2(33) \\
4(67)\end{array}$ & 0.819 & $\begin{array}{c}0(0) \\
20(100)\end{array}$ & $\begin{array}{c}1(5) \\
18(95)\end{array}$ & 0.299 \\
\hline $\begin{array}{l}\text { Use of artificial } \\
\text { nipples }\end{array}$ & $\begin{array}{l}\text { Yes } \\
\text { No }\end{array}$ & $\begin{array}{l}1(20) \\
4(80)\end{array}$ & $\begin{array}{c}0(0) \\
6(100)\end{array}$ & 0.251 & $\begin{array}{l}18(90) \\
2(10)\end{array}$ & $\begin{array}{l}17(89) \\
2(11)\end{array}$ & 0.957 \\
\hline Breast problems & $\begin{array}{l}\text { Yes } \\
\text { No }\end{array}$ & $\begin{array}{l}2(40) \\
3(60)\end{array}$ & $\begin{array}{l}2(33) \\
4(67)\end{array}$ & 0.819 & $\begin{array}{c}9(45) \\
11(55)\end{array}$ & $\begin{array}{l}11(58) \\
8(42)\end{array}$ & 0.421 \\
\hline Birth weight & $\begin{array}{l}\leq 3000 \mathrm{~g} \\
>3000 \mathrm{~g}\end{array}$ & $\begin{array}{l}1(20) \\
4(80)\end{array}$ & $\begin{array}{l}2(33) \\
4(67)\end{array}$ & 0.621 & $\begin{array}{c}7(35) \\
13(65)\end{array}$ & $\begin{array}{c}3(16) \\
16(84)\end{array}$ & 0.170 \\
\hline
\end{tabular}

Analysis of the differences between the groups was performed by test $(\chi)^{2}$, with $p<0.05$ significance. $\mathrm{UH}=$ University Hospital; $\mathrm{HMB}=$ human milk bank; $\mathrm{EBF}=$ exclusive breastfeeding; $\mathrm{NEBF}=$ non-exclusive breastfeeding; $\%=$ percentage $; \mathrm{ES}=$ elementary School; $\mathrm{HS}=$ high school; $\mathrm{MW}=$ minimum salary.

Table 4: Factors associated with the interruption of exclusive breastfeeding among mothers, Taubaté, São Paulo, Brazil

\begin{tabular}{|c|c|c|c|c|c|c|}
\hline Variables & Categories & n (\%) & $\begin{array}{c}\text { EBF up to } \\
6 \text { months } \\
n(\%)\end{array}$ & Or & CI 95\% & $\mathbf{p}$ \\
\hline Maternal Age & $\begin{array}{l}<30 \text { years } \\
\geq 30 \text { years }\end{array}$ & $\begin{array}{l}26(51) \\
22(43)\end{array}$ & $\begin{array}{l}5(19) \\
6(27)\end{array}$ & 1.725 & $0.45-6.64$ & 0.425 \\
\hline Number of children & $\begin{array}{l}>1 \\
\leq 1\end{array}$ & $\begin{array}{l}22(43) \\
28(55)\end{array}$ & $\begin{array}{l}8(36) \\
3(11)\end{array}$ & 0.21 & $0.05-0.92$ & $0.030 *$ \\
\hline Work & $\begin{array}{l}\text { Yes } \\
\text { No }\end{array}$ & $\begin{array}{c}8(16) \\
42(82)\end{array}$ & $\begin{array}{c}0(0) \\
11(26)\end{array}$ & - & - & - \\
\hline Schooling & $\begin{array}{c}\text { Full ES } \\
\text { HS and/or higher }\end{array}$ & $\begin{array}{l}12(23) \\
38(75)\end{array}$ & $\begin{array}{l}3(25) \\
8(21)\end{array}$ & 0.8 & $0.18-3.66$ & 0.774 \\
\hline Family income & $\begin{array}{l}1 \text { to } 3 \mathrm{MS} \\
4 \text { to } 10 \mathrm{MS}\end{array}$ & $\begin{array}{l}41(80) \\
9(18)\end{array}$ & $\begin{array}{l}8(19) \\
3(33)\end{array}$ & 2.063 & $0.42-10.08$ & 0.365 \\
\hline $\begin{array}{l}\text { Marital status } \\
\text { (live with spouse) }\end{array}$ & $\begin{array}{l}\text { No } \\
\text { Yes }\end{array}$ & $\begin{array}{l}5(10) \\
45(88)\end{array}$ & $\begin{array}{l}4(80) \\
7(15)\end{array}$ & 0.046 & $0.004-0.48$ & $0.001 *$ \\
\hline $\begin{array}{l}\text { Use of artificial } \\
\text { nipples }\end{array}$ & $\begin{array}{l}\text { Yes } \\
\text { No }\end{array}$ & $\begin{array}{l}36(71) \\
14(27)\end{array}$ & $\begin{array}{c}1(3) \\
10(71)\end{array}$ & 87.5 & $8.76-873.83$ & $<0.001 *$ \\
\hline Breast problems & $\begin{array}{l}\text { Yes } \\
\text { No }\end{array}$ & $\begin{array}{l}25(49) \\
25(49)\end{array}$ & $\begin{array}{l}4(16) \\
7(28)\end{array}$ & 1.842 & $0.46-7.32$ & 0.382 \\
\hline Birth weight & $\begin{array}{l}\geq 3000 \mathrm{~g} \\
>3000 \mathrm{~g}\end{array}$ & $\begin{array}{l}12(23) \\
38(75)\end{array}$ & $\begin{array}{l}2(17) \\
9(24)\end{array}$ & 0.920 & $0.20-4.16$ & 0.913 \\
\hline Source institution & $\begin{array}{l}\text { HMB } \\
\text { UH }\end{array}$ & $\begin{array}{l}25(49) \\
25(49)\end{array}$ & $\begin{array}{l}5(20) \\
6(24)\end{array}$ & 0.792 & $0.27-3.03$ & 0.733 \\
\hline
\end{tabular}

Or: Odds ratio with significance $\mathrm{p}<0.05$ index. $\mathrm{n}=50 . \mathrm{UH}=$ University Hospital; $\mathrm{HMB}=$ human milk bank; $\mathrm{CI}=$ confidence interval; $\mathrm{n}=$ sample number; $\%=$ percentage; $\mathrm{ES}=$ elementary school; $\mathrm{HS}=$ high school; MS = minimum salary. 


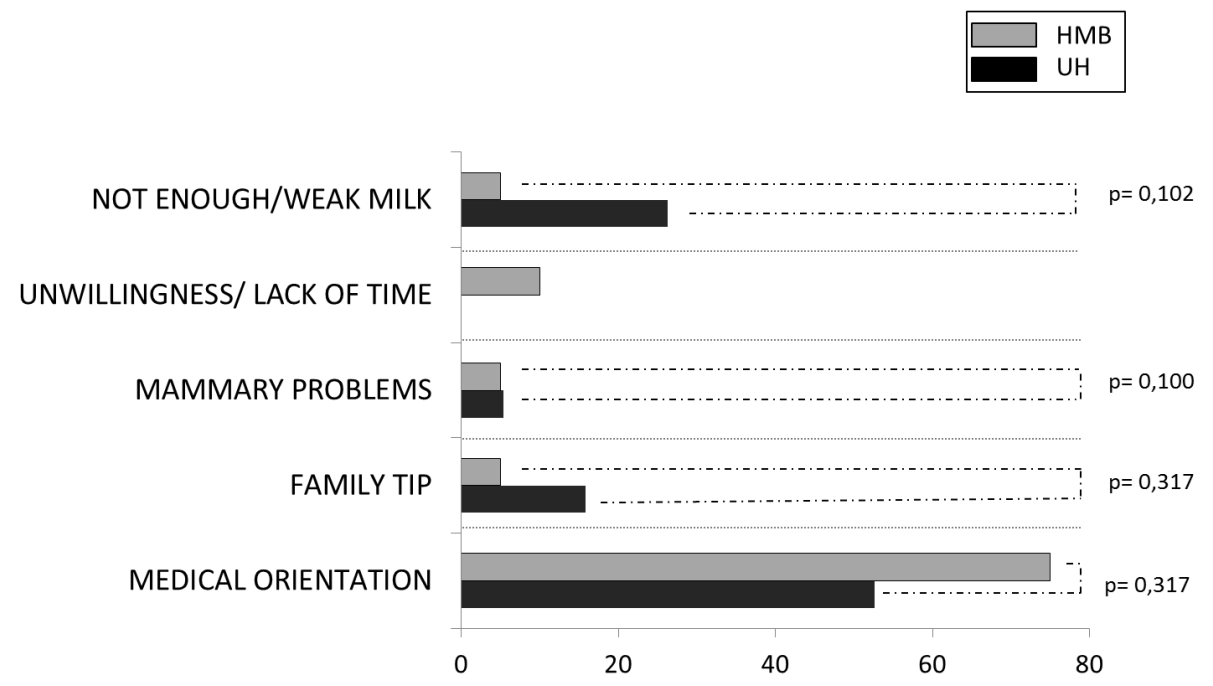

Minas Gerais, Brazil (32.11\%). In this sense, Ferreira et al.15 noted one of the determinants of early weaning to be the lack of guidance for nursing mo-thers, however, some authors believe that information about breastfeeding practices alone is not enough to motivate women to breast-feed. Santos Andrade and Silva ${ }^{16}$ suggest that breastfeeding is not effective through guidance alone, making it necessary to train and educate mothers, so that they have full confidence in being able to breastfeed their infants.

Arguments like this lead to reflect that the interruption of exclusive breastfeeding before the infant's sixth month of life is actually much more complex than supposed ${ }^{17}$. Several findings in the literature have pointed to socioeconomic factors as having an effect on the early weaning process, factors that can affect the act of breastfeeding both oriented and non-oriented mothers. The present study noted a higher frequency of work outside home and fewer children among mothers in the HMB group who discontinued EBF before six months. When analysing the overall study population, the number of other children over a year old in a family was shown to reduce the risk of EBF interruption, as consistent with the results of Damião ${ }^{17}$ and Oliveira et al. ${ }^{18}$ These authors found, respectively, a rate of EBF $50 \%$ lower in working mothers and a higher prevalence of EBF over four months (69.8\%) among mothers who had breastfed previously.

On the other hand, factors such as low education and low income dominated among mothers of the UH group who discontinued EBF early. In the overall study population, not living with a partner reduced the risk of EBF interruption, showing that the absence of a partner had a protective effect on EBF. The use of artificial nipples increased in the risk 87.5 times. The association between early weaning and such factors is also reported in other studies, always with an emphasis on the use of artificial nipples ${ }^{19,20,21}$. The only contrary finding to the literature concerns the relationship between presence of a partner and early weaning. In general in the literature, the presence of a companion is related to a longer duration of breastfeeding ${ }^{18}$, although the importance of spousal support is questioned, and there is also influence from education and maternal age in those results ${ }^{21}$.

It appears, therefore, that the practice of EBF until the sixth month of an infant's is not only motivated by maternal desire, environment can exert a strong influence on the decision to breastfeed. The current study found medical advice as the cause of early discontinuation of exclusive breastfeeding. When researching the prevalence of EBF in a basic health unit at Porto Alegre, Rio Grande do Sul, Brazil, Calegari ${ }^{12}$ found the main grounds for early weaning to be medical advice (24.6\%). Oliveira et al.18 noted the importance of knowledge about breastfeeding in early weaning and emphasised the responsibility of health professionals to support women during breastfeeding. An important point to note is the kind of guidance received by the mothers in the HMB group, as there was no specific pattern to issues addressed during consultations, or the number of visits to the institution. With the report of interviewees who have had passed by medical care in the institution, it is possible to find, albeit with no significant difference, a smaller percentage in breastfeeding's benefits orientation in mothers who stopped EBF in the first semester. Almeida et al. ${ }^{22}$ point out that there are many factors that interfere with the practice of EBF, and lack of knowledge is them.

When compared to data from the literature, the average number of visits made by mothers of this study to HMB was below the number believed to increase the duration of EB, as described by some authors ${ }^{23-26}$. Morrow et al. ${ }^{23}$ compared a control group to two groups who attended 3 or 6 visits in order to provide information about breastfeeding, and found a difference of 17 percentage points in the frequency of EBF in favour of the group attending more visits. Of all children evaluated in the study by Barros ${ }^{24}$, two-thirds made three or more visits to lactation centres, and these showed greater adherence to EBF for six months compared to those with fewer queries. Coutinho et al. ${ }^{25}$ compared a group of mothers receiving maternity guidance to mothers who additionally were visited 10 times after birth, found that the group that received home visits had a higher EBF proportion. A recent meta-analysis 
analysed the effect of postnatal counselling on the duration of EBF in low and average-income ${ }^{26}$. The authors found that the studies present numerous experimental differences, but that counselling determined a relative risk of 0.46 for the interruption of exclusive breastfeeding compared to the control group. The authors emphasise the need for more studies to compare the effectiveness of interventions in order to identify the ideal time and spacing of visits to child health programmes ${ }^{26}$. Frequent and continuous contact with breastfeeding advocacy groups thus proves helpful in combating early weaning.

Although $92 \%$ of mothers who sought the BLH presented problems associated with breastfeeding, which could be a limitation of the study, it is important to note that the observed breast problems were similar in both groups; $40 \%$ of mothers at $\mathrm{BLH}(n=2)$ and $33.3 \%$ of mothers at HU $(n=2)$.

Therefore, so not only the guidance but also other factors identified in this study are associated with breastfeeding, and these factors may also influence the search guidance about breastfeeding.

The results have identified socioeconomic factors inappropriate incentives such as the introduction of new foods before the sixth month of

\section{REFERENCES}

1. Aguiar $\mathrm{H}$, Silva AI. Aleitamento materno a importância de intervir. Acta Med Port. 2011; 24:(S4)889-96.

2. Konstantyner T, Taddei JAAC, Oliveira MN, Palma D, Colugnati FAB. Riscos isolados e agregados de anemia em crianças frequentadoras de berçários de creches. J Pediatr. 2009; 85(3): 209-16. DOI: http:// dx. doi . org/10.1590/S0021 75572009000300005

3. Kramer MS, Kakuma R. Optimal duration of exclusive breastfeeding. Cochrane Database Syst Rev. 2012;8:CD003517. Available from: http://apps.who.int/rhl/reviews/CD003517.pdf

4. Strassburger SZ, Vitolo MR, Bortolini GA, Pitrez PM, Jones $M H$, Stein RT. Erro alimentar nos primeiros meses de vida e sua associação com asma e atopia em pré-escolares. J Pediatr. 2010; 86(5): 391-99. http://dx.doi.org/ 10.1590/S0021-75572010000500007

5. Brasil. Ministério da Saúde. Secretaria de Atenção à Saúde. Departamento de Atenção Básica. Saúde da criança: nutrição infantil. Aleitamento materno e alimentação complementar. Caderno de atenção básica n. 23. Brasília: Ministério da Saúde, 2009.

6. Monteiro R. Norma brasileira de comercialização de alimentos para lactentes e crianças de primeira infância: histórico, limitações e perspectivas. Rev Panam Salud Pública. 2006;19(5): 354-62. http://dx.doi.org/ 10.1590/S1020-49892006000500014

7. Venancio SI, Escuder MML, Saldiva SRDM, Giugliani ERJ. Breastfeeding practice in the Brazilian capital cities and the Federal District: current status and advances. J Pediatr. 2010; an infant's life, and the use of artificial nipples can exert negative influences on the duration of exclusive breastfeeding, often ignoring their knowledge about breastfeeding in HMB. These findings highlight the importance of this study, which can serve as a resource for future studies aiming to achieve continuous statistics about the effectiveness of the promotion, protection and support of breastfeeding. The lack of standardisation in the guidelines provided by HMB is a limiting factor, however, which may have resulted in the low prevalence of AME in this group. We must also consider the study design (cross-sectional), which is subject to the recall bias of the participants and the inability to determine cause and effect. These results can be generalised only to the population of the city of Taubaté, where the study was conducted.

\section{CONCLUSION}

Socioeconomic factors and inadequate incentives have a negative influence on the duration of exclusive breastfeeding. A need to provide more frequent standardised counselling for the effective reduction of early weaning was identified.

86(4): 317-24. http://dx.doi.org/10.1590/ S0021-75572010000400012

8. Brasil. Ministério da Saúde. Secretaria de Atenção à Saúde. Departamento de Ações Programáticas e Estratégicas. II Pesquisa de prevalência de aleitamento materno nas capitais brasileiras e Distrito Federal. Brasília: Ministério da Saúde; 2009.

9. Brasil. Agência Nacional de Vigilância Sanitária. Resolução RDC no 171 de 4 de setembro de 2006. Dispõe sobre o Regulamento Técnico para o funcionamento de Bancos de Leite Humano. Diário Oficial da União 05 set 2006. [cited 2012 May 18] Available from: http://www.anvisa. gov.br/hotsite/segurancadopaciente/ documentos/rdcs/RDC\%20 N\%C2\%BA\% 20171-\%202006.pdf

10. Silva SMS, Segre CAM. Fatores que influenciam o desmame no recém- nascido prematuro. Rev Bras Crescimento Desenvolv Hum. 2010; 20(2): 103-13.

11. Narchi NZ, Fernandes RAQ, Dias LA, Novais DH. Variáveis que influenciam a manutenção do aleitamento materno exclusivo. Rev Esc Enferm USP. 2009; 43(1): 87-94. http://dx.doi.org/ 10.1590/S0080-62342009000100011

12. Calegari DP. Prevalência de aleitamento materno exclusivo em crianças com cinco meses acompanhadas em UBS. Monografia (Especialização Saúde Pública) - Universidade Federal do Rio Grande do Sul. Porto Alegre: 2009.

13. Hulley S, Duncan MS, Schimidt MI, Duncan BB. Delineando a pesquisa clínica: uma abordagem epidemiológica. Porto Alegre: Artmed; 2008; p.384.

14. Caldeira KMS, Souza JMP, Souza SB. Overweight and its relationship with duration of 
breastfeeding in preschoolers. J Hum Growth Dev. 2015; 25(1): 89-96. http://dx.doi.org/ 10.7322/jhgd.96786

15. Ferreira LM, Santos LAS, Alves LCC, Vasconcelos EOF, Pires GS. Os principais motivos do desmame precoce para as mães atendidas em um hospital público de Belém, PA. Trabalho apresentado no $X$ Encontro Latino Americano de Pós Graduação da Universidade do Vale do Paraíba. São José dos Campos: 2010.

16. Santos JS, Andrade M, Silva JLL. Fatores que influenciam no desmame precoce: implicações para o enfermeiro de promoção da saúde na estratégia da saúde da família. Informe Promoção Saúde. 2009; 5(2):26-9.

17. Damião JJ. Influência da escolaridade e do trabalho materno no aleitamento materno exclusivo. Rev Bras Epidemiol. 2008; 11(3):442-52. http://dx.doi.org/10.1590/ S1415-790X2008000300011

18. Oliveira JS, Joventino ES, Dodt RCM, Veras JEGLF, Ximenes LB. Fatores associados ao desmame precoce entre multíparas. Rev Rene. 2010; 11(4): 95-102.

19. Pereira RSV, Oliveira MIC, Andrade CLT, Brito AS. Fatores associados ao aleitamento materno exclusivo: o papel do cuidado na atenção básica. Cad Saúde Pública. 2010; 26(12): 2343-54. http://dx.doi.org/10.1590/S0102311X2010001200013

20. Barbosa MB, Palma D, Domene SMA, Taddei JAAC, Lopez FA. Fatores de risco associados ao desmame precoce e ao período de desmame em lactentes matriculados em creches. Rev Paul Pediatr. 2009; 27(3): 272-81. http://
dx.doi.org/10.1590/S0103-05822009000 300007

21. Brito H, Alexandrino AM, Godinho C, Santos G. Experiência do aleitamento materno. Acta Pediatr Port. 2011; 42(5):209-14.

22. Almeida GG, Spiri WC, Juliani CMCM, Paiva BSR. Proteção, promoção e apoio ao aleitamento materno em um hospital universitário. Ciênc Saúde Coletiva. 2008; 13(2):487-94. http:// dx.doi.org/10.1590/S1413-81232008000 200024

23. Morrow AL, Guerrero ML, Shults J, Calva JJ, Lutter C, Bravo J, et al. Efficacy of home-based peer counselling to promote exclusive breastfeeding: a randomised controlled trial. Lancet. 1999; 353(9160): 1226-31. http://dx. doi.org/10.1016/S0140-6736(98)08037-4

24. Barros FC, Semer TC, Tonioli Filho S, Victora CG. Avaliação do impacto de Centros de Lactação sobre padrões de amamentação, morbidade e situação nutricional: um estudo de coorte. Rev Bras Epidemiol. 2002; 5(1): 5-14. http://dx.doi.org/10.1590/S1415-790X 2002000100003

25. Coutinho SB, de Lira PI, Lima MC, Ashworth A. Comparison of the effect of two systems for the promotion of exclusive breastfeeding. Lancet. 2005; 366(9491): 1094-100. http:// dx.doi.org/10.1016/S0140-6736(05)67421-1

26. Sudfeld CR, Fawzi WW, Lahariya C. Peer support and exclusive breastfeeding duration in low and middle-income countries: a systematic review and meta-analysis. PLoS One. 2012; 7(9): e45143. http://dx.doi.org/10.1371/journal. pone. 0045143

\section{Resumo}

Objetivo: Identificar quais fatores sociodemográficos estão associados ao desmame precoce e comparar a duração do aleitamento materno exclusivo entre mães que receberam orientações sobre aleitamento materno e mães que não receberam. Método: Estudo transversal realizado com 25 mães orientadas sobre aleitamento materno no Banco de Leite Humano e 25 não orientadas, provenientes de um Hospital Universitário. Os dados foram coletados por meio de questionário estruturado abordando dados relacionados à mãe, ao lactente e ao aleitamento materno no primeiro semestre. Comparação e razão de chances foram as análises estatísticas adotadas. Resultados: Não houve diferença significativa na duração do aleitamento materno exclusivo entre os grupos $(p=0,524)$. Entre as mães que interromperam precocemente o aleitamento materno exclusivo, menor número de filhos ( $p=0,034)$ e maior frequência de trabalho materno $(p=0,022)$ foram observados. Já, no segundo grupo a baixa escolaridade $(p<0,001)$ e a menor renda $(p=0,009)$ foram mais frequentes. Na população total, associaram-se à interrupção do aleitamento materno exclusivo o número de filhos inferior a $1(O R=0,21 ; p=0,030)$, presença de cônjuge $(O R=0,046 ; p=0,001)$ e a utilização de bicos artificiais $(O R=87,5 ; p<0,001)$. O motivo mais citado para tal interrupção foi a orientação do médico em ambos os grupos. Observou-se inexistência de um padrão específico de orientações prestadas no Banco de Leite Humano, além de uma média de consultas inferior ao recomendado na literatura. Conclusões: Fatores socioeconômicos e incentivo inadequado exercem influência negativa na duração do aleitamento materno exclusivo. Observa-se a necessidade de fornecer orientações padronizadas e mais frequentes às lactantes, para redução eficaz do desmame precoce.

Palavras-chave: aleitamento materno, desmame precoce, bancos de leite; leite humano. 